SARE, Vol. 55, Issue 1 | 2018

\title{
Historicity and the Contemporary \\ Theatre of Kuo Pao \\ Kun and Krishen Jit
}

C. J. W.-L. Wee

Nanyang Technological University, Singapore

SARE: Southeast Asian Review of English, Vol. 55, Issue 1, 2018 


\title{
SARE, Vol. 55, Issue 1 | 2018
}

\begin{abstract}
What is the place of contemporary art forms from the 1980s within the present global dispensation in which the attempt to obliterate temporality transpired, as witnessed in the Hegelian revivalism of Francis Fukuyama's The End of History and the Last Man (1992)? This essay suggests that the contemporary of contemporary art in Singapore and Malaysia is less a period style and more a differing artistic response to the end of temporality as a situation. The idea of contemporary art entails the existence of an idea of the contemporary. Temporality, in turn, is to be comprehended as the way time is conceptualised and lived out in society. The contemporary is both an idea of the time in which we are in and a goal of reacting more effectively to the demands of the immediate present. And a part of the 1980s was a sense that earlier regional formations of modern art that had eradicated traditional cultural forms as backward needed to be rethought. The artistic practices of Singapore playwright and director Kuo Pao Kun (1939-2002) and Malaysian director Krishen Jit (1939-2005) are major examples of such artistic responses. Their work incarnates a contemporary in which historicity, cultural memory, and interpretations of traditional art forms had roles. Their overlapping theatre commitments require us to see their engagement with the issue of plural identities within and without the modernising nation-state (for Kuo) and within the boundaries of the modernising nation-state (for Jit) in the decades of the 1980s and 1990s, when that great modern ideology of nationalism was being revamped by globalising imperatives. They represent a shared engagement with a common colonial-era Malayan legacy of multiracialism and state formation from the Cold War. Historicity for Kuo and Jit is not the modernist desire to reconstruct the fragments of the past into a whole, and is not centrally about the representation of the past (though that occurs), but is in the first instance the need to capture the past's fragments in order to conceive a fuller sense of the present's multicultural opportunities.
\end{abstract}

Keywords: the contemporary, historicity, theatre, Malaysia, Singapore, Kuo Pao Kun, Krishen Jit,

What is the place of contemporary artforms from the 1980s within the present global dispensation - one within which the attempt to obliterate temporality transpired, as witnessed in the Hegelian revivalism that marked Francis Fukuyama's The End of History and the Last Man ${ }^{1}$ (1992), with his thesis on the end of ideological conflict after the fall of the Berlin Wall? The cultural critic Fredric Jameson has commented that the 1980s "seem to mark the end of the modern in all kinds of ways, from communications technologies and industry all the way to forms of art" (qtd. in Baumbach et al. 140). Do all forms of contemporary art inevitably embody the "end of temporality" that, Jameson argues, is endemic to a general condition of postmodernity (Jameson 695-718)? The term "postmodern", now less deployed in literary-cultural criticism, may not be adequate as a descriptor for the cultural situation, not least because the modernist belief in progress has not entirely disappeared - certainly not in the economic, social and cultural developments linked with the emergence, within the region, of the (so-called) Asian Economic Miracle of the 1980s, and later with China's occupation of the region's economic centre after the 1997 Asian economic crisis. The contemporary moment is marked by a complex or even contradictory blend of an "authentic" progress combined with both postmodernism's well-known rhetoric of the decentred, the multiple, and the heterogeneous and the need for (or the inability to relinquish) a sense of history, if the present's plural fulness is to be allowed effective testimony.

I want to suggest that the contemporary of contemporary art in parts of Southeast Asia - specifically Singapore and West Malaysia - is less a period style but more a differing artistic response from various (though linked) contexts of desired economic growth to the end of temporality as a situation. The idea of 


\section{SARE, Vol. 55, Issue 1 | 2018}

contemporary art entails, as a presupposition, the existence of an idea of the contemporary. The structure of temporality, in turn, is to be comprehended as the way time is understood, or conceptualised, and lived out in society. The contemporary is therefore both an idea of the time in which we are in and a goal of reacting more effectively to the demands of the immediate present. And a part of the 1980 s moment of the present was a sense that earlier regional formations of modern art that had eradicated more traditional cultural forms needed to be rethought.

Capitalist development beyond the levels that colonialism allowed is part of the cause for this thinking. While the global system of Otherness that colonialism created was substantially weakened by postwar decolonisation, the question of economic equality was still a thorny matter in the 1980s. The reappearance of the world market intensified a two-way interpenetration of First and Third Worlds such that countries like Singapore and (West) Malaysia desired to obliterate the non-synchronous socio-economic temporalities that the poles of London and Singapore or Kuala Lumpur, Malaysia's capital city and financial centre, represented. With "the end of an essentially modernist field of political struggle in which the great ideologies [such as nationalism] still had the force and the great authority of the great religions", as it has been put, and states like Singapore seeming less the past of modern states in the West, it might have seemed time to proclaim the "disappearance of History as the fundamental element in which human beings exist", given the expanding blandishments of the "new transnational "culture-ideology of consumption" (Jameson $55,69)$. But the contemporary visual and dramatic arts that emerged in that decade did not abandon the questions of history and historicity (Wee, "The Singapore Contemporary and Contemporary Art in Singapore"). Instead, a more confident theatre scene came to interrogate previous progressive artistic forms that did not have a space for the traditional — and not in the name of pre-colonial nativist purity, but in the interests of manifesting present complexity.

The general artistic practices of Singapore playwright and director Kuo Pao Kun (1939-2002) and Malaysian director Krishen Jit (1939-2005) are major examples of such artistic responses. Their work incarnates a contemporary in which historicity, cultural memory, and interpretations of traditional art forms had roles. Their overlapping theatre commitments - one as playwright and director, and the other solely as a director - are impossible to understand if we do not see their engagement with the issue of plural identities within and without the modernising nation-state (for Kuo) and within the boundaries of the modernising nation-state (for Jit) in the decades of the 1980s and the 1990s, when that great modern ideology of nationalism was being revamped by globalising imperatives. While this essay gives Kuo a little more attention, their work taken together represents a shared engagement with a common colonial-era Malayan legacy of multiracialism and state formation during the Cold War. Historicity for Kuo and Jit is not the modernist desire to reconstruct the fragments of the past into a whole, and is not centrally about the representation of the past (though that occurs), but is in the first instance the need to capture the past's fragments in order to conceive of a fuller sense of the present's multicultural opportunities. There is no "before" to return to for them.

The 1980s and 1990s are the key decades at hand. For Singapore, the initial haste of postindependence modernisation is left behind, and in place is a strengthening will to being contemporary. The renewed economic goals exceeded 1960s-1970s industrial modernization to becoming a top player within the so-called "Asian renaissance" and - a 1990s phrase - in the "Coming Asian Century." For Malaysia, the ascendance of Dr. Mahathir Mohamad as prime minister in 1981 had witnessed vigorous attempts to diversify the economy away from agriculture to manufacturing, technology, and knowledge-based industries, with the result being a more confident assertion of Malaysia's place in the world by the 1990s. 


\section{SARE, Vol. 55, Issue 1 | 2018}

Kuo and Jit's reactions to the modernising and the later globalising impetuses had a direct result in the forms and formation of their contemporary art.

\section{"Singapore ... is the Product of Forgettings"}

We begin with Singapore. Janadas Devan, a leader writer with the Straits Times in the late 1990s, in a conference on heritage issues contended: "Singapore, in many ways, is the product of forgettings. Singapore occurred, and continues to sustain itself, as a result of recurrent acts of forgettings. Forgetting is the condition of Singapore"3 (22). The city-state, like West Malaysia, deals with the question of how to constitute a national identity given a plural population and the perceived requirements of postcolonial state formation, and also given the context of the Cold War and the Malayan Emergency (1948-1960). Singapore's solution was to warn against championing ethnic particularities and to focus on the modern economic and social structures shared by all, "regardless of race, language or religion", as the 1966 National Pledge went. From the late 1960s, the city-state became among the earliest countries to benefit from the increasing economic interdependence of the world system, initially described in 1977 as the New International Division of Labour (NIDL), and only later as outsourcing and, more generally, globalisation ${ }^{4}$ (Fröbel et al.).

Singapore left the Federation of Malaysia in 1965, and the ruling People's Action Party (PAP) government's post-independence survival plan for the intense modernising of the island-state's society and culture to create a viable export-oriented industrial modernity required political stability. ${ }^{5}$ Apart from the restive trade unions, inter-racial tension - what the British had called "communalism" or "racialism" needed to be tamed. The 1964 clashes between Malays and Chinese that occurred on 21 July and 2 September were much cited by the state in the decades that followed as justification for its tight policing of racial discourse (Clutterbuck 8; Lau 162-169, 195-197). The endgame of defusing and forgetting, as much as was possible, ethno-cultural differences, combined with the industrialisation process and substantial urbanisation and infrastructural development, would be the creation of a globally oriented community in which there was a reasonably level economic playing field for all ethnic groups. But these development plans unsurprisingly entailed cultural and other costs to be paid. ${ }^{6}$

Kuo Pao Kun reemerges in the arts scene in 1980, after being detained without trial for four years and seven months. The state alleged that he had been a member of the Malayan People's Liberation League, a splinter group of the Malayan Communist Party; his detention was part of the last anti-communist sweep in the 1970s. ${ }^{7}$ After his release, Kuo abjures his older social-realist conventions (albeit partially leavened by his understanding of Bertolt Brecht's alienation effect [Verfremdungseffekt]). ${ }^{8}$ Ironically, Mao Zedong had passed away only a few months after his detention, and by the end of 1978, the economic reforms called "Socialism with Chinese characteristics" in the People's Republic of China had transpired. The most difficult moments of the Cold War effectively were over for the city-state, and the world that Kuo steps out into is one in which multinational capitalism has a now-established presence in the city-state.

After his release, Kuo's cultural work engages with the impact of the Singapore state's social engineering from the 1960s, manifest in both educational and language policy and the massive transformation of the cityscape - arguably the "products of forgettings": 


\section{SARE, Vol. 55, Issue 1 | 2018}

[W]e treated our heritage as baggage. And, to lighten ourselves, we gave up our mother tongues as first languages, staked our futures in imported cultures, and then turned much of what remained of our physical heritage into theme park like exotic commercial spaces. (Kuo, “The Substation Artistic Director” 327)

National development forcibly "forgets" cultural complexity (and thus also cultural memory and identities) to build a homogenised, forward-looking culture friendly to capitalism, as part of the systematic subsuming of Singapore under capitalism. An expressionist, multilingual theatre that valued historicity and pluralism starts to appear in Kuo's work from the mid-1980s, a theatre that is a reaction to the PAP state's modernising telos:

[C]onfronted by such a [socio-cultural] crisis, we have naturally turned to excavating our deeper memories, hoping to evolve a new vision, one that could more fully express our human potential, one which may get us out of this limbo, leading us into a larger, richer, multi-dimensional cultural grid for the future. ${ }^{9}$ (Kuo, "The Substation Artistic Director" 327)

However, it is vital to note that his critique of a philistine and petit-bourgeois comprehension of modernity is not confined to the PAP state: the region itself, he feels, should reassess the modern culture it wanted, and embrace the plural as a superior way of living in the contemporary, globalising present. The greater wealth Asia possessed by the 1980s should lead to less-insecure formations of culture than occurred before.

In a 1993 conference presentation on contemporary Chinese-language playwriting at the Chinese University of Hong Kong, "Time/Space with a Simple Gesture", we see a direct articulation of the fundamental innovations in Kuo's theatre practice, particularly from 1985. He notes that when he was detained under the Internal Security Act, he evaluated the sort of realist theatre he had attempted in the 1960s and the 1970s, with Ibsen and Stanislavsky as the dominant models. The detention years were significant for him for the ending of the Cultural Revolution. Kuo's pre-1980s approach to theatre, as we might expect, was the legacy of the 1919 May Fourth reformism in China, which "upheld modern Western concepts as progressive and classical Chinese Art and traditional concepts (Chinese opera included) as conservative, feudalistic, reactionary"10 (Kuo, "Time/Space with a Simple Gesture" 156). The enforced interregnum in his life led to an awareness that his particular Chinese, "Mao-inspired" (156), cultural background, given the "westward-looking" (ibid. 156) nature of May Fourth, has led to a "bias against traditional forms and concepts" (ibid. 156), and also against the "folk traditions" (ibid. 157) that Brecht - a playwright he much respected - had shown an interest in. ${ }^{11}$ The anti-colonial moment of modern Chinese cultural history, ironically, led to an absorption of Western artistic-cultural practices inimical to the local. A genuinely progressive and postcolonial modernising of culture in the present therefore should move away from the old colonial telos of historical trends that left behind all things traditional, understood of course as a synonym for the backward. The modernising impulse and its connection with forgetting was scarcely a solely Singapore challenge.

What does Kuo relearn, then, of the traditional? Rereading Jerzy Grotowski's Towards a Poor Theatre (1968), with Grotowski's particular conviction that "essential theatre [w] as nothing more than a confrontation between a naked actor and a single spectator" ("Time/Space with a Simple Gesture" 157), leads Kuo to a conviction that the actor could become "almost the sole instrument of expression", and that 


\section{SARE, Vol. 55, Issue $1 \mid 2018$}

(pace Grotowski's own method) "training should be a subtraction exercise (dispelling tension and releasing inhibitions) rather than an additional exercise (acquiring skills and technique)" (ibid. 157). Chinese theatre tradition before the advent of modern huaju (or spoken) drama (vs. sung drama, xiju, or Chinese operatheatre) offered precedents for contemporary theatre experimentation in "subtraction".

Kuo also becomes convinced that the artistic process could be more important than a finished mental image of the production, for the interaction between director and actors could result in a "mutual[ly] enriching/inspiring/developing process" ("Time/Space with a Simple Gesture" 157). These ideas of "developing process" had gone into the devising of his own play, OZero01 (1991), which used the metaphor of the salmon swimming upstream to spawn in relation to four performers who excavate memories in their own bodies pertaining to cultural origins and family histories to live better in the present. This process leads to the actor's body becoming expressive enough to evoke time and space, freeing theatre from the need for realistic sets:

On reflection, Chinese classical [sung] theatre has influenced me most in its concepts of a flexible space/time. Rooting its expressive power almost entirely in the performers acting in an empty space, gestures alone create the entire universe of a traditional Chinese play. Such poverty/richness cannot communicate realism. ... Xuni (literally meaning omitting and suggesting) allows the performer to create any time/space with a simple gesture. And the audience responds/participates with an equally rich imagination. All the major Eastern theatres share this 'empty space' aesthetics. As I am constantly exposed to Indian and Indonesian theatre which are also part of Singapore's culture, it has become more and more difficult to say that my influence has come solely from the Chinese theatre. ("Time/Space with a Simple Gesture" 160)

The impetus for an understated artistic iconoclasm comes both from reading Western theatre thinkers and reassessing the value of traditional Chinese theatre forms in the context of the discrediting of certain revolutionary period imperatives. The move away from realism can free the expressive body, and this for Kuo is not exclusively a Chinese cultural impetus, but one influenced by Southeast and South Asia.

The question then is how a revivified notion of the traditional is pertinent to theatre that should no longer function as if within the insecure, colonial-era need to become modern. In a keynote address to the Asian Art Festival in Tokyo, on 29 October 2000, Kuo tells his audience:

For 100 years, new theatre in Asia drank from the spring well [sic] of the West Europe and America. [...] The larger and deeper reason for this [artistic-cultural] development was Asia's entry into the Modern Age. In Japan, the process was voluntary. For almost all the other Asian countries, the process was often a violent engagement with the colonial powers, including those of Japan. ("A Reflection of Theatre in Asia" 198-199)

Kuo's sweeping re-evaluation of theatre practice finds inadequate modern cultural formations in Asia, where the enforced need to modernise also came from a Japan that itself deliberately became, with the 1868 Meiji Restoration, the region's first modern nation-state — and in the process also adopted the colonialist 


\section{SARE, Vol. 55, Issue $1 \mid 2018$}

orientation that was embedded in that era's model of the liberal nation-state. In the post-war new that Asia exists in, many postcolonial societies have "achieved varying degrees of economic affluence" (Kuo, "A Reflection of Theatre in Asia" 199). And "riding on the crest of this new[er] wave [of the new], a deep transformation is, again, radically reshaping theatres in Asia" (ibid. 199), with "Non-Realistic" (ibid. 200) theatre formats coming to the fore: we can now remember that once which had to be forgotten, and be new in a way that better captures contemporary life.

Kuo resorts to specialised Chinese terminology to describe the new artistic developments. Citing Huang Zuolin (1906-1994) - who had studied with Michel Saint-Denis in England in the 1920s and who was the first to teach Stanislavsky technique in China; and who significantly in 1962 advocated a more eclectic type of huaju that could blend in traditional Chinese theatre - Kuo uses the term xieyi, "the theatre of the East, which he [Huang] also called "ideographic theatre" ("A Reflection of Theatre in Asia" 200). The description here is of what may be paraphrased as the suggestive or perhaps gestural form of body expressiveness theatre that Kuo tries to integrate into plays such as his monodrama The Coffin is Too Big for the Hole (1985) and the multilingual Mama Looking for Her Cat (1988).

The reason for a focus on the body in reconditioned performance forms, Kuo speculates, is not some sort of revivified nationalistic nativism: "Indeed, in this day and age, if a renaissance [of culture] is at all possible anywhere in this world, ... it would have to be a renaissance of world cultures" ("A Reflection of Theatre in Asia" 203). Cultural renaissance should benefit everyone. Regional specificity should not, for Kuo, exclude global thinking. A "deeper reason for this profound change" in artistic practice is that

people living in urban centres, where information technology has increasingly become a fact of life, have been increasingly drawn to a new mode of work which uses almost only the head and the hand. [...] I believe that this new mode of working and living has in turn given rise to a new appreciation of the human body. [...] Because the development of human body-centred theatre arts is very much in harmony with this new awareness, it enhances appreciation of the human as an individual. ("A Reflection of Theatre in Asia" 201)

That is, increasing urbanisation and the revolution in communications that Kuo had witnessed from the 1980s could be taken as undergirding body expressiveness. The working out of a gestural-body theatre rejoins "the head and the hand" with the body, and makes fuller the individual.

What must be resisted is not newness per se but "the consumerist market" and the "culture of entertainment", for they expel "memory" (Kuo, "A Reflection of Theatre in Asia" 205): the "colossal global market force [...] has seduced theatre to play the short-term memory game" (ibid. 206). Kuo disapproves of the enhanced commercial culture lined with the globalised economy: his leftist artistic history showed a connection with the genuinely "popular" culture of the urban working class and rural folk culture, and that Utopian legacy continues with his maintenance of a zone of authentic experience against commercial culture. A terrible result is that we might even forget twentieth-century violence committed by states:

[We have witnessed] the most murderous one hundred years in history: more wars have been fought and more people have been killed than ever before. This has been especially true in Asia - even till today. ... The bizarre destruction of China's Cultural Revolution and the Tiananmen Square suppression, along with 


\section{SARE, Vol. 55, Issue 1 | 2018}

recent happenings in Afghanistan, Iraq, Myanmar, Indonesia and Timor are histories that are hardly complete; in fact, they are all crying to be remembered and made sense of. (Kuo, "A Reflection of Theatre in Asia" 205)

The body, gestural-expressive theatre, cultural memory, and freedom - are all linked in Kuo's understanding of the calling of contemporary theatre in a world where the historical arrival of modern developments both created violence and offered (and still offers) new possibilities for nurturing human potential: "Finding itself a new role in the globalising and consumerist world seems to me to be the fundamental crisis our theatre is going through now. How will it resolve this crisis?" ("A Reflection of Theatre in Asia" 208). He had, as yet, no answer.

For Kuo, our moment of the present requires reflexive artistic-cultural experimentation. The difficulty for art lies in the ahistorical and even anti-historicist impulses of the Consumerist Now, impulses that were released in early form in the late 1960s in the Singapore state's modernising imperatives and arguably found a fuller expression from the 1980s, when Singapore gained confidence as a more advanced society catching up with the metropolitan West.

\section{Kuo Pao Kun's open, interpretive text}

Given Kuo Pao Kun's metacritical reflections on theatre, what forms did his plays take? While he did not simply stop using realist elements, there is consistent experimentation, from the mid-1980s until his passing away in 2002, in both his Chinese-language and English-language versions of his plays. He removed the need for sets and a proscenium arch theatre, and emphasised the actor, his/her language, and his/her body. Using the bare stage, simple as that may sound, he wrote in 1992, is part of a "moving out of the proscenium form", which is also "a move away from realism. In turn, this means [crucially] shifting away from the representational towards the presentational approach", which for "the classical theatres in the East" has "a strong epic, ritual and ceremonial quality, ... [functioning in place of] lifelike facsimile" (Kuo, "Heart of the Arts" 148). How plays can become presentational such that the epic and the ceremonial enter the present rather than being merely the life-like representational is the question, and rethinking earlier artistichumanistic resources is the answer.

At times, Kuo's plays have characters that are types, such as the Mother and the numerous Children in the workshopped/devised Mama Looking for Her Cat. That play examines the rapid alienation of a nonMandarin-speaking (and instead Chinese-“dialect" speaking) Mother from her Children, given the state's post-independence fostering of Mandarin-Chinese and English as more rational and economically viable languages - and the loss of the Mother Tongues and cultures that that led to. The acting also took on expressionist and even muted surrealist dimensions. A central and continuing concern was the necessity to think of form in relation to the thematisation of memory, so vital in his work. There is also the need for a more literal remembering, such as in the largely realistic Kopitiam (The Coffee Shop) (1986), in which a grandfather tries to convince his grandson who wants to live in Canada of the need to maintain the family kopitiam as a viable business, given what it represents of the grandfather's past toil and immigrant roots, and the community linked to it, when faced by the threat of the state's acquisition of the property in the city core for urban redevelopment. Then, there is the recall of a semi-mythicised personage such as Zheng He (or Cheng Ho,1371-c.1435), the Ming Dynasty explorer-diplomat admiral, in Kuo's theatrically minimal and 


\section{SARE, Vol. 55, Issue $1 \mid 2018$}

stage-direction-free Descendants of the Eunuch Admiral (1995), ${ }^{12}$ invoked to propound how the legend still could speak to us in the globalised present. Kuo says in an interview in 1992 that "the most difficult thing [for contemporary theatre] is finding a form", and that form must "aim for a kind of openness, or interpretive type script" (Sharma 183-189). This openness in form seems part-and-parcel of the openness of the globalising present itself; that, combined with a sense of historicity, will allow a vital reassessment of the present.

On occasion, the thematisation of the historical-traditional is very pointed. In this regard, Kuo's Lao Jiu - The Ninth Born (English-language version 1993) stands out. A teenage boy forfeits the blandishments of examination-based meritocratic success for a dissipating and seemingly irrelevant puppetry tradition and its imaginative world. Kuo writes in the 1990 programme for the Chinese-language version of the play that Lao Jiu featured various types of "artistic and cultural resources":

Here, three types of puppetry are being incorporated: the Fujian hand puppetry directed by Lee Chye Ee, shadow puppetry directed by Somsak Kanha of MAYA, Thailand, ${ }^{13}$ and man-sized puppets choreographed by Goh Lay Kuan. Low Ee Chiang taught the cast pugilistics, Phoon Yew Tien composed and arranged the music, and Choo Ping Chyuen coached us on [Chinese] dialects. ${ }^{14}$ ("Lao Jiu: The Lao Jiu Attempt...” 267)

Lao Jiu, one could say, is artistic-cultural indigeneity worn on one's sleeve.

However, the most indicative manifestations of Kuo's gestural form of body expressiveness that aims to become presentational, enabled by an open, interpretive text, are probably the monodrama and, later, the monologue. While the 1985 monodrama The Coffin is Too Big for the Hole has no direct incorporation of elements from traditional sung theatre, the script - with no supportive stage directions to guide interpretation - puts an actor on a bare stage, and it is up to the actor and the director to fill the stage with his presence and conjure the dilemma at hand. An unnamed everyman experiences the unsettling memory of his grandfather's funeral: "I don't know why, but it keeps coming back to me. This dream. Every time I get frustrated it comes back to me" (Kuo, Coffin 1). The irrepressible memory becomes a metaphor for disrupted socio-cultural life. The cortege arrives at the burial site only to realise that the old-style, Chinese coffin is too big for the new standard-sized funeral plot hole. As the eldest grandson, it is the protagonist's filial duty to see his grandfather off properly, and he tangles with the authorities over this inflexible, standardised state culture, and the play puts a spotlight on the city-state's bureaucratic modernity with an understated, mordant humour. ${ }^{15}$

The filial grandson recounts what the civil servant in charge of the cemetery finally pronounces:

\footnotetext{
"All right. Since you are already at the cemetery, and since the coffin has proven itself too big for the hole, we'll make this case a very special exception. Because we don't want people to misunderstand us, to read us as being disrespectful of traditions, as being hard and unaccommodating to even the dead. But listen, and listen well!"
}

He looked straight into the funeral man's face as he continued, "There will only be this one exception and no such requests will be entertained ever again. One 


\section{SARE, Vol. 55, Issue 1 | 2018}

man, one grave, one plot! See that you make sure each and every one of them will be put in a coffin that is just right for the standard size of my graves!" (Coffin 8)

Modern values are pronounced, but yet there is a disjunctive feudal paternalism in the civil servant's language. The modern man becomes both a supplicant to an imperial Authority (an enforced semi-ritualised role) and an old-style, folksy story-teller, who once functioned on the roadside, performing for a then lessliterate Singapore. By pragmatically executing both roles, the protagonist unexpectedly fulfils his traditional filial responsibility. However, the quotidian epic of everyman takes place in the present and so he directly engages with the impact of the Weberian iron cage of rationality wrought by the PAP state in the late 1960s and 1970s. While Coffin does not obviously invoke traditional form, the open script and the vocabulary of both the protagonist and the civil servant constitute the play's "presentational approach" that allows in the "epic, ritual[istic] and the ceremonial" into the present.

When we come to the English-language version of Descendants of the Eunuch Admiral, written a decade after Coffin, we see the monodrama reworked into a variety of related monologues, interspersed with occasional dialogues, and assembled into a set of painful, self-aware reflections on contemporary man's emasculated condition in the global arena. These reflections are marked as episodic scenes rather than as acts per se and appear fragmentary, though the central issue of bodily/cultural loss links them all. ${ }^{16}$ As in Coffin, there are no helpful stage directions, making the play stripped down and radically stark - perhaps making it the ultra-representational play. The eunuch admiral, as with the old-style coffin, comes to contemporary consciousness as a disruptive memory or, indeed, nightmare. Descendants uses Zheng $\mathrm{He}$ - born Muslim, then forced into "being" Han Chinese so as to represent the Ming state in his travels, and neutered in the interests of creating a reliable state servant who has a flexible identity - as an allegory of the fate of man's cultural identity put in the high service of representing a "globalising" state that is more than ever, in the play's 1990s context, conscious of a multicultural, world-wide market. Despite this, the freedom gained by the state's servant by being outside the confines of national territory also is real. In Scene 13 , the unnamed narrator ceremonially and grandiloquently intones:

Grand Eunuch Zheng He, faithful servant of the Ming Emperor, was sent to the Western Ocean as an imperial emissary to blaze a trail of glory for the Middle Kingdom. Never did he expect to leave a path of amazing splendour that would seep into the lives of so many people in so many places, through so many ways over so long a time ... (Kuo, Descendants 249)

Of course, the contemporary world has as much exploitation as Zheng He's, and it is not that the world-wide market is "simply" free. However, the uprooted state of the castrated man does forcibly enable him to search: "But the eunuch admiral seemed never to have given up the hope of finding an alternative life" (Kuo, Descendants 253). The play ends with a poem uttered by the Zheng He character, indicating how literal and metaphorical travel within a global market is simultaneously freedom and servitude:

\section{I cannot tarry}

I must hurry

The sea, the land, the sky is waiting

The market is calling me! (Kuo, Descendants 254) 


\section{SARE, Vol. 55, Issue 1 | 2018}

Descendants suggests that man lives within a capitalism so enlarged that it seems well-nigh universal.

The Singapore Condition of emasculated modernity in Descendants is transposed to an epic allegorical level via an almost mythic "Chinese" personality to indicate what is increasingly a general condition of life within the roving presence of global capital: this is a world related to yet not entirely the same as the more nationally astringent and confined mid-1980s moment of Coffin. Logical rationality in the 1990s has a (problematic) place for the less-rational component of cultural identity. The open text of Coffin with its single body of the supplicant-story teller becomes expanded into a play of 16 scenes, with no precisely discernable bodies. There is no list of dramatis persona, but there is a nameless narrator in the present, thinking back to the past - the main voice. There are those in the past who chose or were coerced to become eunuchs. Zheng He is on a few occasions allowed direct voice, but is not a realistic character. Sometimes he can only speak in the entrapped, ceremonial language of the imperial state servant, and yet finds individual freedom within that role. The question of the play is how or what contemporary globalised man learns from Zheng He. Kuo's text is more open than any earlier, and any director of this presentational play must interpret, must think of how the actor (or actors) can fill the stage and how the body can suggestively express history for the present — and a present that needs be cautious of the nation-state's globalising ambitions.

\section{Krishen Jit's inclusive contemporary national theatre}

If Singapore can be said to be the product of state-sponsored forgetting, Malaysia, in contrast, is the result, arguably, of state-sponsored reiterative rememberings — the two countries offer revealing contrasting reactions to what was once a common plural society. Krishen Jit's intracultural theatre counter-remembers so as to quiz and then inflect the post-independence Malaysian construction of national culture, and to offer an inclusive socio-cultural present. Unlike Kuo, who becomes leery of the dangers of the national impetus by the 1990 s, Jit consistently presents a complex identity within a national schema; and he continues thus even as Kuala Lumpur transforms in the 1980s, when Prime Minister Dr Mahathir "generated a burgeoning modernization and liberalism [that exceeded the older style industrial modernisation envisioned in the 1970s], alongside a growing [socio-cultural] conservatism" (Rajendran 87). ${ }^{17}$

Certainly, as with Singapore, the socio-economic changes shaped by capitalism by the 1980s that licensed an imaginative sense of increased synchronicity with the advanced West also generated new complexities in the way artistic culture and, also, religious-cultural identities transmuted. Are the new plural artistic cultures to be taken as an advance on how Singapore and Malaysia can be represented, or are they the (inadvertent) multicultural superstructure of a multinational capitalism (Žižek 29-51)? In both cases, I suggest that the artistic processes are disaggregated enough to facilitate semi-autonomous forms of humanistic and artistic enquiry: Kuo and Jit's work can be taken as postcolonial counter-articulations of new modern culture to represent their respective societies' contemporary moment. Capitalism's facilitation of artistic development is part of the moment of this region's present.

To fully comprehend the directions Jit's directorial practice took, we need first to return to the "older" modernist moment of the new, of national independence, when History was being made, and British Malaya becomes converted into, first, the Federation of Malaya in 1957, and then into Malaysia in $1963 .{ }^{18}$ If citizenship in multiracial Singapore meant the need to disregard race, mandated by the PAP state that 


\section{SARE, Vol. 55, Issue 1 | 2018}

proclaimed itself to transcend inter-racial strife, this would not work in Malaysia. The Malay-Chinese riots of 13 May 1969, unlike the 1964 riots in Singapore, led to an affirmative-action programme: the formulation of the 1971 New Economic Policy (NEP) better enfranchised the majority Malay population, as they wielded political but not economic clout. The socio-economic challenges were addressed by the NEP's aim to change the ratio of corporate equity ownership from 2.4:33:63 (of bumiputera [Malay: prince or son of the soil] ${ }^{19}$ /other Malaysian/foreigner ownership) to $30: 40: 30$ by 1990 . Though Jit was of Punjabi extract, he was Malayan-born and was committed to addressing the question of what it meant to be Malaysian, given the issues that led to the NEP.

The starting point to think upon Krishen Jit's theatre practice is that though he shared with Kuo Pao Kun similar conceptions of a contemporary theatre practice - and also knew him well - he was not on the left-leaning side of post-independence national formation. In 1971, Jit co-authored a significant policy paper with other members of the literary intelligentsia entitled "Teaterku... Di Mana Akar Mu?" (in Malay, "Our Theatre ... Where are Your Roots?"), which advocated, among other points, a less-urban-and-elite-oriented theatre for a teater rakyat (people's theatre). But while Jit backed the formation of a Malay-language national culture - for which he was much criticised - he did not back a purist and elevated vision of Malay identity in a multi-racial Malaysia, though the very title of the policy paper in this regard did him no favours. As he entered the 1970s, he stopped participating in English-language theatre in favour of Malay-language theatre (Rajendran 55-68). ${ }^{20}$ However, the Malay-language phase ended in 1979 when, as the artistic director of a retrospective of nine modern Malay plays for the Malay Studies Department of the University of Malaya, he encountered a critical, nativist reception. Thereafter, he re-entered English-language theatre, and eventually created multi-lingual theatre that engaged the everyday life of ordinary people in Kuala Lumpur. Slowly, though, English also will be regarded by some less as the language of His Master's Voice and more the global language of business and multiculturalism.

Despite Jit's disappointment with the 1970s, the overall directorial approach that will mark his complex, culturally layered mature work appears in embryonic fashion in that decade. He experimented with traditional art forms and casting actors who could be at odds in class, ethnic or (later) even gender terms with the roles to be played. Further, Jit also used modes of staging that were either fragmented or non-linear in order to actualise cultural dimensions not directly perceptible in the script. This is teater kontemporari (contemporary theatre), clearly identifiable in Malaysia by the mid-1970s - unlike in Singapore, where contemporary theatre only emerged in the 1980s. Apart from the use of indigenous art forms, it also incorporated absurdist and expressionist elements. Teater kontemporari divorced itself from drama moden (modern drama), which came about earlier in the 1950s and 1960s and deployed realistic or naturalistic styles infused with local content and written in Malay. It became disfavoured for "contemporary playwrights viewed realism as a Western form of theatre that was inappropriate in an era of intensified efforts to promote Malay culture" (Nur Nina 42). (Thus, contemporary theatre emerges in West Malaysia at a point when Kuo Pao Kun's social-realist theatre will contribute towards his detention.) What will change from the 1980s is that Jit's inclusive contemporary national theatre expands into a multilingual and expansive interdisciplinary theatre: the "inclusive" becomes amplified and directly addresses urban culture, in the years when there are attempts to make Kuala Lumpur more of a global city.

To return to the 1970s, the commitment to the perceived forward movement of a nationalist History has its entailments, and the need to valorise a Malay (rather than Malaysian) national culture is opposite to Singapore's homogenising, capitalist-cultural formation in the same decade. Malaysia took on what the PAP 


\section{SARE, Vol. 55, Issue 1 | 2018}

in the 1960s called a Malay Malaysia (vs. a Malaysian Malaysia) policy of national identity formation. Both nation-building approaches were alternative ways of dealing with cultural pluralism.

Despite the fact that Singapore attempts to fill in the nation-state, via social engineering, with a more culturally homogenised population, and Malaysia remains more faithful to the great modernist ideology of nationalism and the creation of a unified national culture, in the 1970s, teater kontemporari captured well the dislocations caused by Malaysian attempts to modernise. Singapore of course was not the only postcolonial society to embrace development: the United Nations in 1961 had declared that that decade would be the Decade of Development ${ }^{21}$ (UNICEF, “The 1960s: Decade of Development”). Jit's own 2003 reflections on the 1970s are revealing:

[The decade] was also a period when there was a strong sense of transition between people moving from the country[side], from the kampong (village), into the city - particularly young people. And this transition was paralleled by the transition between traditional cultures and values and what might be called contemporary cultures and values. [...] It was reflected not only in the content, but in the form of theatre, where the living together of traditional and contemporary theatres lent strong images to the stage. (qtd. in Rajendran 62)

The social and cultural disjunctures and transitions required both new theatrical content and form; and the new required the old, or how else could we understand the actual transition taking place? Ironically, Jit's commitment to a Malay-language theatre was fulfilled by his capturing the decentred, the multiple and the heterogeneous.

Jit's 1975 direction of Tok Perak by Syed Alwi (1930-2008), which received the 1974 National Literature Award (Drama), is indicative of the approach to experimentation that would continue into his mature work. ${ }^{22}$ Tok Perak is an itinerant medicine seller who attempts to settle down with a family in the royal, but still small, town of Kuala Kangsar. Despite marriage to a local woman, he is still regarded as an outsider, as his beliefs do not sit comfortably with the increasing acceptance of more scientific, Western medicine and the religious conservatism of the Malay-Muslim community he is in the midst of: he represents an important part of Malay heritage that seems out of sync with the times. Tok Perak returns to his itinerant existence.

Jit's experimentation with the staging of plays sees him, first, casting urban and educated actors to play small-town folk, suggesting that the play should not be taken as examining only rural life. Syed Alwi himself plays Tok Perak, and as such the latter's individualistic eccentricity is implied to be actually as modern as that of the artistic individual. Non-Malay actors are also cast: "If Tok Perak is a Malay folkcharacter associated with a vanishing Malay way of life, then those who travel with him and to whom he returns at the end, are [cast with] a mix of Malay and non-Malays, [and this remakes him into 'being'] ... Malaysian, and not just Malay" (Rajendran 74). Second, Jit makes the play an inter-media affair: he notes that "the play juxtaposed folk performance events (silat, wayang kulit, and the versifying syair), modernistic images from film and slides, with an intricately textured realistic play. The mixed means performed was an analogue of the protagonist's state of mind" (55). He fragments the realistic script, and the mix of the modern and the traditional both inflects for the audience the tensions within Tok Perak's mind and, vitally, makes visual the various external stresses affecting him that are, so to speak, outside the realm of the script 


\section{SARE, Vol. 55, Issue 1 | 2018}

proper. This inter-media format is the third aspect of Jit's experimentation. The past "in" the present makes us rethink how the present can be (re-)staged.

The nationalist demands for a teater rakyat may prefer a monumental, vertical singularity of Malay identity, but Jit creates a play in which the horizontal dimensions of socio-cultural life are emphasised. National identity and its components in Tok Perak are depicted as varied and relational, and marked by difference: the rural and the urban, traditional and modern cultural media, Malays and non-Malays — they exist in relation to each other.

The 1980s witness an intensification of the directorial approaches of the 1970s, with attention paid to stylised performance and the creation of non-linguistic layers of signification. The return to the Englishlanguage theatre, though, offers a more even-handed engagement with multicultural identities, given that it is not a "racialised" language - though the change did suggest that experiments with a teater rakyat return to the realm of the educated, urban middle class. However, the new emphasis here is that English is a Malaysian language, and not just the language of the former coloniser. It is therefore a legitimate means in the present to investigate rooted identities. In 1984, Jit directs K.S. Maniam's English-language play, The Cord, which examines the abusive power dynamics between the English-educated Muthiah (a rubber-estate administrator), Muniandy (a scrupulous estate worker), his wife Lakshmi, and Ratnam (Muthiah's biological son, the result of his raping Lakshmi). A key intent is to think through how an immigrant cultural identity can be reinvented in a new national context. Malaysian-born Ratnam, in contrast to his parents' generation, valorises not Muniandy's $u d u k u$, a small traditional drum, but a Yamaha motorcycle, a materialistic symbol encompassing ideas of wealth and power in the new Malaysian world. Jit cast an urban, English-educated Chinese playwright as Muthiah, extending the experimentation seen in Tok Perak. This complicated the idea of power in the play, probably reminding the audience that the Chinese were seen as the comprador class during the colonial period - and in the event also reminding the audience that the politics of rural workers are interconnected with those of the urban centre (Rajendran 1-50).

As Jit goes through the 1980s, the historical context of Kuala Lumpur life changes, and the change needs to be factored in if we are to comprehend the additional changes in Jit's fully developed 1990s and 2000s theatre practice. One change occurs in 1980, when he goes to New York University for nine months on a fellowship funded by the American Council of Learned Societies. There, his theatrical and performative vocabularies are extended, and he meets the performance scholar and theatre director Richard Schechner. Encountering the work of artists such as Spalding Gray (1941-2004), known for his autobiographical monologues, Jit sees that he can "recast the intersubjectivity between actor and spectator by challenging the audience to interpret the [performance] work as a spontaneous and improvised text, rather one in which ideas were thematically structured and unified" (Rajendran 99). Jit can be free from the script, and he can work out directly the intracultural realities on the ground into a performance, and the devices previously experimented with can find a new way to be manifested. Another change is that Kuala Lumpur gains global ambitions under Dr Mahathir. As Jit's work often dealt with the "changing cultural and literal urbanscape of the capital city Kuala Lumpur [... becoming] Jit's primary site for theatre invention" (Rajendran and Wee, 18), it behoves us to reflect on economic changes and their impact on urban culture in the federal capital to see how his new devised theatre facilitated the presentation of an implicitly globo-national Kuala Lumpur.

The late 1980s saw Kuala Lumpur's global reorientation, though of course the city was already the recognised commercial and political core of Malaysia. The East Asia region itself witnessed an understanding that urban development meant being part of global political and economic networks; and so, what was new for the Malaysian developmental agenda was "a need for specifically urban-centred strategies 


\section{SARE, Vol. 55, Issue $1 \mid 2018$}

for globalization" (Bunnell et al. 361). This global outlook witnessed by the construction of the César Pellidesigned Petronas Towers from 1993, when excavation works started on the original, late-nineteenth-century site of the Selangor Turf Club for the new complex - supermodernity sitting on top of a former colonial-era institution. The National Development Policy (1990-2000), which supported privatisation and technological advancement, replaced the NEP, and some distance from 13 May 1969 facilitated renewed explorations of intercultural existence beyond that possible in the 1970s; but now pluralism also could be deployed by the state. In 1999, Tourism Malaysia announced its "Truly Asia” campaign - Malaysian diversity is allowed to sell the nation itself (IBS Centre for Management Research). However, this hardly signified a liberalmetropolitan multiculturalism. While Mahathir launched the ideal of Bangsa Malaysia (Malaysian race or nationality) in 1991, the practical entailments of this goal were never quite clear.

Nevertheless, the 1990s were not the 1970s, and Jit's devised work "exceeded ... [his] earlier work, in that they went beyond cultural fusions and blurring boundaries to assert a layered inter-connectedness" (Rajendran 122). Jit's devised Us: Actions and Images (1993) is one result of his late work. Clearly, from the title alone, the question is who and what constitutes this "us" now, especially the younger "us". He undertook the work as a collaboration with five actors in their 20s - three women and two men, who were Malay, Chinese, and a Sri Lankan-Eurasian of Sinhalese origins, of varied class levels. Some hailed from rural areas, though all lived in Kuala Lumpur. The performance had improvised scenes drawn from the actors' lives and acted out in a fragmentary manner, with different languages used, but with no translations offered, which reflects the day-to-day experience of urban inter-ethnic interactions.

One scene had the actors telling stories of how their parents were married: "The five juxtaposed stories were drawn from memories of marriage urban and rural, marriages traditional and modern in form, marriages among the English-educated and the unschooled. ... The actors interrupted and at points even participated [in] each other's stories" (Rajendran and Wee, 20). And thus an interwoven "us" is projected, even if no simple coherence is offered. But neither is there the presence of the state's neat racial taxonomies. The intense experience of the city with globalising imperatives, as with the historic Western cities of artistic modernism, may deracinate, may dislocate, but something new also emerges from the cultural losses (Bradbury). At the same time, while a more globalised city is the backdrop of the performers' lives, Us: Actions and Images is also a reminder of the specificity of Kuala Lumpur's grounded multicultural identities: on display is a qualified globo-national identity, but not an image of cosmopolitan rootlessness. Jit's intracultural theatre stages the decentred, the multiple, and the heterogeneous for Malaysian edification, but is not a theatre aiming to join the flows of a decentred global culture.

\section{A Tale of Art in Two Cities}

The art critic Boris Groys has written: "Modern art is (or, rather, was) directed toward the future. Being modern means to live in a project, to reduce it to a permanently self-effacing moment of transition from past to future" (quoted in Smith 7). From one art-critical perspective, when modernism declined and visual arts practices changed in the 1960s-1970s, contemporary (as opposed to modern) art began to rework what it meant to live in a project, acknowledging the power of the present, with the term contemporary functioning "as a soft signifier of current plurality" (Smith 7). If we accept these definitions of modern and contemporary art (obviously in the Euro-American context), we must say that modern art and theatre in Malaysia and Singapore has never been entirely modernist, even while many artists were forward-looking in their socio-cultural orientation. Singapore and Malaysia's shared arts historically had to contend with a 


\section{SARE, Vol. 55, Issue 1 | 2018}

present time of past things, especially the living inheritance of the colonial creation of a multiracial and thus plural society, particularly during the nation-building phase of the post-independence period from the $1960 \mathrm{~s}$ to perhaps the 1980s. As has been observed, "empire's structure of government was necessarily organized around the accommodation of diversity, albeit according to an imperial hierarchy" (Young 31); nationalism does not always accommodate such diversity. There could be no fully convincing "self-effacing moment", even in the decades when "socialism" (for Kuo Pao Kun) and "national culture" (for Krishen Jit) were synonyms for "Utopia".

As a post-industrial understanding of the economy took hold, the possibilities widened for a contemporary theatre in which the plural is acknowledged. In Singapore, where sustained foreign investment led to an economy dominated by multinational corporations, Kuo experimented with presentational dramatic forms inspired by Chinese sung theatre from the mid-1980s, believing that the non-nostalgic use of the traditional was a positive urban-cultural response to the opportunities of the new info-tech world. By the 1990s, in Kuala Lumpur, with a more cosmopolitan new generation historically more removed from fraught discussions of 13 May 1969, Jit was able through devised intercultural theatre to explore memory, forgetfulness, and multi-layered racial identities. The $1980 \mathrm{~s}-2000 \mathrm{~s}$ witnessed a shared contemporary theatre that stepped back from the present so as the re-stage the present's possibilities.

However, circumstances have changed. The nature of the cultural pluralism Singapore arts engage with have moved towards the personal being the political, to use a 1960s-inspired cliché, and more globalised gender themes, including LGBT issues, have emerged. Racial sensitivities of course exist, and are still explored. State funding for the arts from the 1990s has flowed in amounts unimaginable in the 1970s, and arts audiences have expanded, though censorship continues. There are sections of the state desiring creativity to support economic innovation. The result of such rapid transformations is that the direction of the contemporary arts is not clear.

In contrast, the roles for cultural pluralism in Kuala Lumpur, despite the economic changes signified by the Twin Towers, have changed less. Indeed, its being the federal capital implies a painful day-to-day confrontation with the racialised political difficulties that tripped up both the ideals that led to independence in 1957 and the attempts to rework such difficulties through the NEP. Immediate post-independence questions of race have intensified. Further, unlike the 1990s, there are less state-sponsored alternative theatre events by private companies, so that what occurs on the "official" (and maybe on the "corporate") and the experimental stages has widened. Also, the more experimental artists undertake such work irregularly. Additionally, there are few leaders for such work, partly because of funding issues and partly because of a lack of certainty of the political in relation to the artistic, given the state's assertive stance from the late 1990s. The immediacy of political realities pushes people into political party activism. ${ }^{23}$

Despite common socio-cultural origins, Singapore, the quasi-authoritarian city-state committed to the open flows of global capital and which suppressed cultural differences, and Kuala Lumpur, the federal capital of Malaysia, with a history of Malay nationalism and a related history of quasi-authoritarianism but spread over a much larger land area, have parted ways - inevitably. But the shared ghosts have not disappeared: J.S. Furnivall (1878-1960), the British colonial civil servant who had coined the term "plural society" for racially complex colonial societies such as Burma, did not use that term positively. Our postindependence societies are still sorting that issue out. 


\section{SARE, Vol. 55, Issue 1 | 2018}

\section{NOTES}

${ }^{1}$ Fukuyama first announced his thesis in his essay "The End of History?", published in The National Interest, no. 16 (Summer 1989), pp. 1-18. With the firm global emergence of China after the Asian financial crisis of 1997, and with the 2008 financial crisis, it is much less clear what the current contemporary moment represents - but it hardly seems a world that is posthistoire.

${ }^{2}$ The phrase "Asian Renaissance" was first used in 1996 by the then deputy prime minister of Malaysia, Anwar Ibrahim, who also offers the humanistic provocation that an Asian "rebirth" in the wake of economic progress should concern itself with "the revival of the arts and the sciences under the influence of classical models based on strong moral and religious foundations; a cultural resurgence dominated by a re-flowering of art and literature, architecture and music and advancements in science and technology" (The Asian Renaissance [Singapore: Times Books International, 1996], 18). And so, the arts indeed, in Singapore and in Kuala Lumpur, become vital, though not quite based on the "classical" and "religious foundations" Anwar mentions.

3 Janadas was appointed director of the Institute of Policy Studies, National University of Singapore, in 2011, and since 2012 is also concurrently the chief of Government Communications.

${ }^{4}$ The original German edition was published in 1977.

${ }^{5}$ The PAP came into power in 1959, when Singapore was a Crown Colony, and has continually remained in charge since then. Singapore shed its colonial status by joining the Federation of Malaysia in 1963.

${ }^{6}$ Cf. Chua Beng Huat, Liberalism Disavowed: Communitarianism and State Capitalism in Singapore (Ithaca, NY: Cornell University Press, 2017); and C. J. W.-L. Wee, The Asian Modern: Culture, Capitalist Development, Singapore (Hong Kong: Hong Kong University Press, 2007).

${ }^{7}$ The government alleged that Kuo "was inducted into the MPLL [Malayan People's Liberation League] in August 1974, four months ahead of his wife, [the ballerina] Goh Lay Kuan, after having been a member of the Malayan National Liberation League" ("The Faces of Subversion. The Red Plot: Target Singapore", Straits Times [Singapore], 28 May 1976).

${ }^{8}$ Cf. Quah Sy Ren, "Intellectual Consciousness and the Negation of the Intellectual Class: Kuo Pao Kun's Pre-Detention Drama and Its Time", Inter-Asia Cultural Studies (forthcoming).

${ }^{9}$ Elsewhere, when asked about subversion, Kuo says, "[I] f you talk about 'subversion' in Singapore, the Singapore government is the biggest 'subversive' force. They subverted the entirety of Singapore and replaced grassroots level totally with the CCs [Community Clubs], CCCs [Citizens' Consultative Committees], the RCs [Residents' Committees], and at so many levels and dimensions! From private life to community life to business to everything they equated the state with government and party even down to kindergarten level. It's internalized! On the one hand, people enjoy it because they are being taken care of" ("Protest, Provocation, Process: Cultural Activism in Singapore: The Necessary Stage, 21 January 2001", in The Complete Works of Kuo Pao Kun, vol. 8: Interviews, ed. Tan Beng Luan [Singapore: Practice Performing Arts School and Global Publishing, 2011], 197). The organisations Kuo mentions are run by the People's Association, a statutory board set up by the Singapore state in 1960, and currently supervised by the Ministry of Culture, Community and Youth; see People's Association, "About Us", https://web.archive.org/web/20070607055309/http://www.pa.gov.sg/1153988278915/1153988278958.html, accessed 9 December 2017.

${ }^{10}$ The original article appeared in TDR: The Drama Review 38, no. 2 (T142) (Summer 1994): 59-63.

${ }^{11}$ Cf. Bertolt Brecht, "Chinese Acting", trans. Eric Bentley, Tulane Drama Review 6, no. 1 (1961): 130-36.

${ }^{12}$ This refers to the English-language version of the play; I will return to this later.

${ }^{13}$ MAYA: The Art and Cultural Institute for Development, Bangkok, Thailand, is an alternative theatre institute and NGO founded in 1981.

${ }^{14}$ The English-language version was directed by TheatreWorks' Ong Keng Sen in 1993. 


\section{SARE, Vol. 55, Issue 1 | 2018}

${ }^{15}$ For an account of the Confucian dimensions of Coffin, see Paul Rae, "The Feeling of Being Watched: Lived Confucianism and Theatricality in Kuo Pao Kun's Mid-1980s Monodramas", Inter-Asia Cultural Studies (forthcoming).

${ }^{16}$ The Chinese-language version is different, and it features prisoners executing a play that deals with Zheng He within the context of the actual play being seen by the audience.

${ }^{17}$ This section draws on Rajendran's central insights on Jit's work in her dissertation. A major exception to Jit's directorial history of multicultures-within-the-nation is the musical-fantasy of pan-Asian cultural identity, Singapore singer-composer Dick Lee's Nagraland (1992), staged in Singapore and then in Japan; see C. J. W.-L. Wee, "Staging the New Asia: Singapore's Dick Lee, Pop Music, and a Counter-Modernity", Public Culture 8, no. 3 (Spring 1996): 505-507. Unfortunately, this musical is outside the scope of this essay.

${ }^{18}$ Malaya gained independence from Great Britain in 1957 as the Federation of Malaya, and in 1963, with Sabah, Sarawak and Singapore, formed the Federation of Malaysia.

${ }^{19}$ The term does not only refer to the Malay population but to any group given a "special position" by the state. Cf. Sharon Siddique and Leo Suryadinata, "Bumiputera and Pribumi: Economic Nationalism in Malaysia and Indonesia", Pacific Affairs 54, no. 4 (Winter 1981-82): 662-87.

${ }^{20}$ Cf. Charlene Rajendran and C. J. W.-L. Wee, "The Theatre of Krishen Jit: The Politics of Staging Difference in Multicultural Malaysia", TDR: The Drama Review 51, no. 2 (T194) (Summer 2007): 14-15.

${ }^{21}$ UNICEF, “The 1960s: Decade of Development", https://www.unicef.org/sowc96/1960s.htm, accessed 25 November 2017.

${ }^{22}$ Syed Alwi's Tok Perak has been republished a number of times by different publishers, but there is no English-language translation of the play available.

${ }^{23}$ This opinion on Kuala Lumpur arts is tentative, and is based partly on a discussion with Charlene Rajendran on 1 November 2014.

\section{WORKS CITED}

Baumbach, Nico, et al. "Revisiting Postmodernism: An Interview with Fredric Jameson." Social Text, vol. 34, no. 2, June 2016, p. 144.

Bradbury, Malcolm. "The Cities of Modernism." Modernism: A Guide to European Modernism 1830-1930, edited by Malcolm Bradbury and James McFarland, Penguin, 1976.

Bunnell, Tim, et al. "Kuala Lumpur Metropolitan Area: A Globalizing City-Region." Cities, vol. 19, no. 5, 2002, p. 361., doi:10.1016/s0264-2751(02)00036-7.

Clutterbuck, Richard L. Conflict and Violence in Singapore and Malaysia, 1945-1983. Graham Brash, 1984.

Devan, Janadas. "Forgetting to Remember." Our Time in Place: Exploring Heritage and Memory in Singapore, edited by Kwok Kian-Woon et al., Singapore Heritage Society, 1999, p. 22.

Fröbel Folker, et al. The New International Division of Labour: Structural Unemployment in Industrialised Countries and Industrialisation in Developing Countries. Cambridge University Press, 1981.

Furnivall, John S. Netherlands India: A Study of Plural Economy. Cambridge, Cambridge University Press, 1967 (First published 1939). 


\section{SARE, Vol. 55, Issue 1 | 2018}

. Colonial Policy and Practice: A Comparative Study of Burma and Netherlands India.

Cambridge, Cambridge University Press, 2014 (First published 1948).

IBS Centre for Management Research. "Tourism Malaysia: Creating 'Brand Malaysia'." Strategic Management|Management Strategy|Business Strategy Case Study|Business Strategy|Case Study|Case Studies, www.icmrindia.org/casestudies/catalogue/Marketing/Tourism Malaysia-Brand Malaysia-Marketing Case Study.htm.

Jameson, Fredric. "Notes on Globalization as a Philosophical Issue." The Cultures of Globalization, edited by Fredric Jameson and Masao Miyoshi, Duke University Press, 1998, pp. 55-69.

. "The End of Temporality." Critical Inquiry, vol. 29, no. 4, 2003, pp. 695-718., doi:10.1086/377726.

Jit, Krishen. "Contemporary Malaysian Theatre." Krishen Jit: An Uncommon Position, edited by Kathy Rowland, Contemporary Asian Arts Centre, 2003, p. 55.

Kuo, Pao Kun. "The Substation Artistic Director Kuo Pao Kun on the Memories Season." The Complete Works of Kuo Pao Kun, Vol. 6: Commentaries, edited by Tan Beng Luan, Practice Performing Arts School and Global Publishing, 2007, p. 327.

. "Lao Jiu: The Lao Jiu Attempt...." The Complete Works of Kuo Pao Kun, Vol. 6:

Commentaries, edited by Tan Beng Luan, Practice Performing Arts School and Global Publishing, 2007, p. 267.

. "Time/Space with a Simple Gesture." The Complete Works of Kuo Pao Kun, Vol. 7:

Papers and Speeches, edited by Tan Beng Luan, Practice Performing Arts School and Global Publishing, 2008, pp. 59-63.

"A Reflection of Theatre in Asia: One Voice from Singapore. Finding a New

Role/Meaning for 21st Century Theatre." The Complete Works of Kuo Pao Kun, Vol. 7: Papers and Speeches, edited by Tan Beng Luan, Practice Performing Arts School and Global Publishing, 2008, pp. 198-199.

"Heart of the Arts: Building on East and West." The Complete Works of Kuo Pao Kun,

Vol. 7: Papers and Speeches, edited by Tan Beng Luan, Practice Performing Arts School and Global Publishing, 2008, p. 148.

"The Coffin Is Too Big for the Hole." The Complete Works of Kuo Pao Kun, Vol. 4:

Plays in English, edited by C. J. W.-L. Wee, Practice Performing Arts School and Global Publishing, 2012, p. 1.

"Descendants of the Eunuch Admiral." The Complete Works of Kuo Pao Kun, Vol. 4:

Plays in English, edited by C. J. W.-L. Wee, Practice Performing Arts School and Global Publishing, 2012, p. 249.

Lau, Albert. A Moment of Anguish: Singapore in Malaysia and The Politics of Disengagement. Eastern Universities Press, 2003.

Nur Nina Zuhra. An Analysis of Modern Malay Drama. Biroteks, Institut Teknologi MARA, 1992.

Rajendran, Charlene. "Staging Difference in Modern Multicultural Malaysia: The Politics of Krishen Jit's Theatre.” Nanyang Technological University, 2012. 


\section{SARE, Vol. 55, Issue $1 \mid 2018$}

Rajendran, Charlene, and C.J.W.-L. Wee. "The Theatre of Krishen Jit: The Politics of Staging Difference in Multicultural Malaysia." TDR/The Drama Review, vol. 51, no. 2, 2007, pp. 14-15., doi:10.1162/dram.2007.51.2.11.

Sharma, Haresh. "People of the Arts: Kuo Pao Kun and Stella Kon." The Complete Works of Kuo Pao Kun, Vol. 8: Interviews, edited by Tan Beng Luan, Practice Performing Arts School and Global Publishing, 2011, pp. 183-189.

Smith, Terry. "Introduction." Antinomies of Art and Culture: Modernity, Postmodernity, Contemporaneity, edited by Terry Smith et al., Duke University Press, 2008, p. 7.

Syed Alwi Syed Hassan, Tok Perak. Kuala Lumpur, Kumpulan Seni Teater, 1974.

“The Faces of Subversion. The Red Plot: Target Singapore." Straits Times, 28 May 1976.

UNICEF. "The 1960s: Decade of Development." UNICEF, www.unicef.org/sowc96/1960s.htm.

Wee, C. J. W.-L. "The Singapore Contemporary and Contemporary Art in Singapore." Charting Thoughts:

Essays on Art in Southeast Asia, edited by Low Sze Wee and Patrick D Flores, National Gallery Singapore, 2017.

Young, Robert J. C. “Postcolonial Remains.” New Literary History, vol. 43, no. 1, 2012, p. 31.

Žižek, Slavoj. "Multiculturalism, Or, the Cultural Logic of Multinational Capitalism." New Left Review, vol. 225, 1997, pp. 29-51. 